\title{
PERFORMANCE-ENHANCING MEDICINES IN SPORTS: LEGAL DISCUSSION
}

\author{
Ahmad Saad Ahmad Al-Dafrawi ${ }^{1}$ \\ A PhD Candidate / Department of Islamic Law, \\ Ahmad Ibrahim Kulliyyah of Laws, International Islamic University Malaysia (IIUM). \\ (Email: manfromnowhere290@gmail.com; saad.aldafrawi@live.iium.edu.my) \\ Mohamad Asmadi Abdullah ${ }^{2}$ \\ Associate Professor / Department of Islamic Law, \\ Ahmad Ibrahim Kulliyyah of Laws, International Islamic University Malaysia (IIUM). \\ (Email: masmadi@iium.edu.my) \\ Majdah Zawawi ${ }^{3}$ \\ Associate Professor / Department of Islamic Law, \\ Ahmad Ibrahim Kulliyyah of Laws, International Islamic University Malaysia (IIUM). \\ (Email: z.majdah@iium.edu.my)

\section{Zainudin Ismail ${ }^{4}$} \\ Assistant Professor, Department of Islamic Law / Ahmad Ibrahim Kulliyyah of Laws, \\ International Islamic University Malaysia (IIUM). \\ (Email: zainuddin@iium.edu.my)
}

Received date: 15-09-2019

Revised date: 13-11-2019

Accepted date: 15-11-2019

Published date: 15-12-2019

To cite this document: Al-Dafrawi, A. S. A., Abdullah, M. A., Zawawi, M., \& Ismail, Z. (2019). Performance-Enhancing Medicines in Sports: Legal Discussion. International Journal of Law, Government and Communication, 4(17), 48-60.

DOI: $10.35631 /$ ijlgc. 417005

\begin{abstract}
Morally speaking, employing Performance-Enhancing Medicines (PEMs) in sports is not acceptable because using these medicines in sports competitions is associated with negative legal consequences. However, due to rapid advances in the genetic modification technologies, there is a fear that these therapeutic technologies have been applied to athletes (e.g., to prevent Myostatin from incapacitating skeletal muscle groups). Additionally, taking and giving performance-enhancing medicines are not only unethical, but such activities could even be illegal because of the dangerous side effects of drugs associated with it. The main issue that this paper is going to discuss in the absence of criminal provisions addressing the actions of doping generally and gene doping in many existing legal systems around the world. Another issue that this paper deals with is the lack of laboratory screening methods that can discover the occurrence of gene modifications. In this regard, this study attempts to examine the legal theory of the development of disciplinary and criminal systems setting athletes' responsibility which definitely arise as a result of utilizing PEMs and employing gene doping technologies in sports competitions. The study uses the analytic method to find out the exact terminologies of these substances which affect athletes and their rights to life bodily integrity.
\end{abstract}


Keywords: Performance-Enhancing Medicines (PEMS), Genetic Modification Technologies, Disciplinary Responsibility, Criminal Responsibility, Sports Fields

\section{Introduction}

Historically, the ancient Greeks participated in physical activities such as sports and mixed it with religious rites. Contestants were mainly from well-known Greek families who were used to compete in assorted sports (Coakley, 2009). It was a normal practice among athletes to use different 'supplements' to overcome exhaustion, injury or boost stamina (Yesalis, 2000). Materials used were bull testicals and intoxicating liquors. However, antique "doping" was prohibited. Emperor Theodosius suspended the conduct of ancient Games in the year 395 AD because of its deceptive character due to consumption of supplements. Later on, "Mariani wine" was used as a supplement. Then, it was barred by legislation of Germany in 1920 (Müller, 2010). Nevertheless, after decades and exactly during the Rome Olympic Games in 1960, the Danish cycler, Knut Jensen died and after examination it was found that he consumed amphetamines and nicotine acid (Møller, 2010). As a reaction to this event, the International Olympic Committee (IOC), took the opportunity to create a regulation which originally based on 'the Ethics Law'. This regulation supposed to stop athletes' consumption of performance-enhancing medicines (Ahmad, 2015). A private international body called the World Anti-Doping Agency (WADA) was established on November 10 ${ }^{\text {th }}, 1999$ (Geeraets, 2018). The fundamental concern of WADA to uphold its Code and prove the gene and cell doping technologies applications. WADA's legal testing system was examined. A major affair that needs to be examined includes answering the following questions. Can the legal system of the disciplinary code deal with acts of doping which are associated with criminal effects? Can the legal system of the disciplinary code dealing with doping be associated with the effects of the crime?

The main reason behind involvement of professional athletes in sports is that it (sport) considers as a lifestyle and a source of income. For amateurs, however, the reasons are likely to be greater health and enjoyment in competitions (Bird, Black, \& Newton, 1997). Human beings were not born with equal physical potentialities and so training will not simply provide what genetics does not provide (Cashmore, 2005). In addition, researchers found that some athletes and their teams would take or give performance-enhancing medicines (PEM) in sports because these things would make them faster, stronger, and more capable of handling any pain. Doping medicines in sports simply gives an athlete an advantage over other athletes who do not dope at all. Previously, taking PEM in sports was considered immoral and for so, it was mutually rejected. Moreover, due to the development of medical testing methods, it has become evident that the consumption of these substances by athletes may lead to death. This has been confirmed by 'The International Convention Against Doping in Sport' (United Nations Educational, Scientific and Cultural organization (UNESCO), 2005). The anxiety of lawgivers to control doping activities in sports is not a minor issue. It is a reversal of the worry which exists inside the community (Atienza-Macías, 2018). All the actions and activities of taking/giving PEM are in fact illegal. The actions constitute a serious violation of law and have two legal implications:

\section{The Rise of Disciplinary Responsibility}

Law society faces this responsibility when the side effects of performance-enhancing medicines are absent. In this hypothesis, WADA Codes would be enough to control these scenarios. 


\section{The Rise of Criminals' Liability}

Law society faces this type of responsibility when actions of taking PEMs come together as one case, with a dangerous side effect and will lead to crime.

\section{Materials and Methods}

In this study, the researchers applied the inductive method to remark the phenomenon and its legal results. Employing the descriptive method gives a clear picture of the study problem, objectives, hypotheses, and recommendations. The researchers will also use the analytical method to help explain the legal meaning of PEMs and to discuss relevant WADA texts and the legal results.

This study tries to be positively involved in legal discussions on the real dimension of taking and giving acts of PEMs in sports and their legal results which affect athletes and their rights to life - bodily integrity. It begins with a historical context and a reference to earlier studies. It follows by clarifying the legal concepts of terms: Performance-enhancing medicines and Doping and Genetic Therapy. Finally, a discussion of the legal results and some possible recommendations are provided. It is hoped that this study will create sufficient awareness among decision-makers on the need to stand against doping activities which normally come together with criminal effects. The effect of such illegal activities would result in departure from the disciplinary responsibility sphere to the criminal liability one.

\section{The Literature Review}

Quite extensive literature has been written on this study from different aspects and the followings are some chosen examples from them.

\section{Medical and Biological Studies}

In a recent biological-medical study, Salamin and his fellows (2017) have shown a new technique which has the potential to be further developed for the detection of foreign genetic materials among professional athletes (Salamin, Kuuranne, Saugy, \& Leuenberger, 2017). The study's team also showed that this testing method doesn't need a very expensive laboratory. Even the cost to use this method is not expensive. However, even though the results of this study are exceptional, it solely constitutes a biological-medical and not a legal study.

\section{Ethical and Philosophical Aspects Studies}

The study of (Russell \& Browne, 2018), is a theoretical study that has been able to address the issue of taking and giving PEDs. It has revealed many weak points in the anti-doping control process. This high academic team of researcher examined social and philosophical side effects of doping. Additionally, the study of (Geeraets, 2018) is one of the few studies that provide a fundamental balance between the concept of idealism, actions and volume of athletes' responsibility and actual roles played by WADA. On the other hand, the study of Nancy Vargas-Mendoza and her colleagues in 2018 made a magnificent effect in concentrating on the legal and ethical aspects.

\section{Legal Aspects Studies}

The study of (Atienza-Macías, 2018) succeeded in linking medical and legal effects dietary supplement consumption. It also reviewed most important international legislation and conventions that dealt with the consumption of dietary supplements containing substances that are banned in sports. 


\section{Conceptual Framework}

Our main goal is not only to define PEMs. Ruther the definition of the term is used as a means to clarify that doping of these substances is not within the therapeutic framework that has a legal connotation. PEMs are non-prescribed materials which are legal in terms of its origin. However, they become taboo and constitute a violation of law according to the nature of its use (Ahmad, Bodybuilding - Training Techniques and Doping Hazards, 2011). Anabolic substances could be employed for treatment and for non-pharmaceutical treatment use (Lenehan, 2003).

PEMs are legally used with patients who have indigence for Androgen therapy, or with children that have growth hormone-deficiency (O'Connor, Budgett, Wells, \& Lewis, 1998). PEMs are also used as a tonic in medical treatment. Athletes are not machines and are prompt to sickness and injury easily. The legislation that deals with PEMs as non-proscribed substances as long as it remains in the therapeutic zone. In this regard, Jackson stated that "Memory-enhancing drugs might be enhancements if they are taken by students preparing for a study evaluation, while it is a stimulating treatment for patients suffering from Alzheimer" (Jackson, 2012). The above legal meaning is mentioned clearly in paragraph (1) art: (4.4) of the WADA Code of 2015:

The existence of a forbidden substance or its metabolites or markers, and/or the use or attempted use, detention or administration or attempted administration of a prohibited substance or prohibited method shall not be considered an anti-doping rule violation if it is harmonious with the provisions of a TUE granted in accordance with the International Standard for Therapeutic Use Exemptions (World Anti-Doping Code 2015, 2018).

\section{Technical and Legal Meanings of (PEMs), Doping, and Genetic Therapy}

Taking and giving PEMs, or even using Genetic modification technologies can be a cause for the rise of disciplinary and criminal responsibility. Therefore, it is necessary to examine in depth the technical and legal meaning of the terms of Performance-enhancing medicines, Doping and Genetic Therapy.

\section{Performance-Enhancing Medicines (PEMs)}

WADA Code does not define the meaning of PEMs. Yet, a sociology Professor Ellis Cashmore said: the pronouncement 'performance enhancement' refers to a style, de jure or not, (the word 'enhance' is from the Old French enhancer, which may be distantly linked to altus, Latin for high). To be clear, a more accurate term would be 'training enhancement' because most aids are ergonomic in effect: they help athletes to energize more efficiently in their environments. Most performance enhancers would enable an athlete to train harder and longer (Cashmore, Sport Psychology: The Key Concepts, 2002). The term "performanceenhancement Medicines" itself, according to the traditional meaning, has been subjected to changes for many times. It is no longer limited to the literal meaning of the word "Steroids.". Its legal meaning has been used with many different terms. For example; the prohibited methods and banned substances now have become an integral part of the legal term of performance-enhancement medicines in sports fields. The Malaysian authorities view physical steroids as a type of poison, because of their harmful effects. They are subject to the provisions of the Poisons Act, 1952. In this regard, we quote from the words of DATUK Eisah A. Rahman, the Senior Director of Pharmaceutical Services, Ministry of Health Malaysia which she said: "We wish to inform that steroids have always been controlled under the Poisons Act, 1952. Androgenic steroids are classified as a Group B poison, of which it can only be sold and supplied by a registered medical practitioner for the purpose of treating 
patients only. A prescription from a registered medical practitioner is required for its sale and supply by a licensed pharmacist. If convicted, any person who is guilty of an offence under the Poisons Act, 1952 may be fined not more than RM5,000 or imprisoned for not more than two years or both" (Rahman, 2013).

\section{Doping}

According to the study of Chan and his colleagues for 2016, terms of "Doping", refers to the illicit employment of performance-enhancing medicines and technicality in sports. It represents a serious crime in the sport that has numerous negative results, including titles being stripped, bans from competing, harms the reputation and so forth. As doping is surmised to be a pre-meditated action, engaging in this behaviour has been predominantly attributed to athletes' decision-making processes and moral values or obligations. A growing volume of literature has focused on the psychosomatic components connected with doping or doping intention, such as motivating force, sportsmanship, and the detachment between ethical and social-cognitive factors (Chan, et al., 2016). Basically, the acts of doping are against the essence of sports. The conflict against doping demands each anti-doping organization to evolve and perform educative strategies and protection programs for competitors (Vargas-Mendoza, Fregoso-Aguilar, Madrigal-Santillán, Morales-González, \& Morales-González, 2018). The athlete takes disallow materials or methods in order to promote his/ her sports condition (Deeksha, Akarsh, R.K, \& U.S, 2017). According to the definition of Doping adopted by the Committee of Ministers of the Council of Europe on 29 June 1967, doping refers to "the management to or use by a fit human being, in any style whatever, of foreigner factors to any creature, or of physiological materials in excessive amounts or introduced by an unusual channel, with the sole goal of affecting artificially and by unfair ways in the performance of such a person when taking part in the race." (Soek, 2006). Moreover, the International Amateur Athletic Federation (IAAF) defined doping by saying in IAAF Doping, rule 55:

(1) Doping is precisely unauthorized and is lawbreaking under IAAF Rules.

(2) The offense of doping takes place when either

(a) an illegal substance is found to be present within an athlete's body tissue or liquids; or

(b) an athlete uses or takes advantage of a verboten technique; or

(c) an athlete confesses having tried or taken advantage of a prohibited substance or a prohibited technique (Gardiner, et al., 2001).

Linguistically, the words like taking or giving should be used to label the unlicensed action of employing anabolic agents in sports. The words of exploitation or use are to describe the use of PEMs for medicinal purposes because its consumption is legal. The Arab lexicographer, Ibnu Manz̄ūr in his dictionary Lisānul- 'Arab (the tongue of the Arabs) says: "the taking denotes the consumption of disallowed substances" (IbnuManzwr, 2003). Additionally, the term dope also includes the followings: "(a) an illegal medicine, such as cannabis: Peddle dope: a dope dealer. (b) or a pill, esp one that causes drowsiness. (c) a substance is taken by an athlete (1) or given to an animal to make them win in a race: fail a 'dope test (ie be found in a medical test to have taken such a drug)." (Hornby \& Crowther, 1998). 


\section{Gene Doping, or Genetic Therapy*}

Evolution of genetic engineering has been of a great benefit, especially for the treatment of many diseases caused by Endogamy, muscular dystrophy, or even getting old. Because of the patients' response to these technologies, a very serious idea has emerged that calls for applying these technologies to healthy athletes in order to obtain genetically modified athletes.

Gene therapy is an essential method in athletic medicine. Genetically modified athletes are easy to visualize. The common uptake of performance-improving drugs in sports refers that plenty of sports rivals will be zealous to avail themselves of genetic enhancement. Gene therapy will likely be misapplied (Minigh, 2007). Therapy includes the genetic modification of human cells guided at treating, preventing or curing a condition. "Gene therapy" expression is often used to refer to genetic modifications (Pattinson, 2011). "Germ-line genetic alteration (hereafter GL-GM): modulations are made on the so-called germ-line cells (sperm, unfertilized eggs or the newly fertilized embryo) to increase their metabolic abilities with the aim to ameliorative health or to enhance athletic attainments. This re-modulation must be done before the affected individual is born. Hence, the results of this formulate of genetic intervention will be inheritable" (Tamburrini, 2007). Regardless of the fact that most gene therapies are not certain, it is probably that sports contenders will not be waiting until the date of clinical admission to try these new techniques to ameliorate their bodies conditions (Salamin, Kuuranne, Saugy, \& Leuenberger, 2017).

Applying these technologies in sports which are in fact a therapeutic technology for the diseased or weak genes could cause the sports competition to change forever. From the legal side, the major dilemma of revitalization by applying these therapeutic technologies is that there are no real testing methods. The reason is that it doesn't go to the bloodstream and also, there are no signs that it can be dismissed by urine. But, "What is the sin of some athletes in having unlimited abilities at the level of athletic achievement if they have been genetically revamped their cells before they even born? Is it permissible to raise their legal responsibilities on a moral basis?" (AL-Dafrawi, 2018).

By reviewing the latest version of Prohibited List 2019, under the category of Prohibited Methods, the art: (M3), of the new list came to confirm the preventing of applying the Gene and Cell Doping techniques, by saying: "The following, with the effort to rise sports performance, are against the law:

1. The capitalize on polymers of nucleic acids or nucleic acid analogues.

2. The utilize of gene editing agents intended to change genome series and/or the transcriptional or epigenetic arrangement of gene code.

3. The use of natural or genetically altered cells." (PROHIBITED LIST, 2019).

- Gene therapy is an encouraging effective technique of redress seriously sick folks, which in some cases results in a remedy of the damage. Theoretically, all existing albuminoid levels in the body may be changed by applying gene treatment. As the first gene therapy trials are performed with doping related proteins, such as EPO and somatotropic hormone, the link between gene therapy and sports is crystal clear. The probable misuse of this type of therapy is a new form of doping: gene doping Invalid source specified.. For further information, please check:

https://www.researchgate.net/profile/Hidde_Haisma/publication/7207790_Gene Doping/links/004635

2b17dbbc65f1000000/Gene-Doping.pdf 
Finally, our disagreement with art: M3 is that it is a fancy article, because in our fields (legal fields) if it is impossible to prove the happening of things, so it is not acceptable to be invoked.

\section{Legal Implication for Employing PEMs in Sport Fields}

It was clearly said in the background of this study that 'All the actions and activities of taking/giving PEMs and anabolic steroids should be outside of the legal framework. Therefore, any act goes in that direction will establish a violation of the law'. In fact, the legal consequences of violating anti-doping rules come in two forms:

A. The rising of Disciplinary responsibility form.

B. The rising of Criminal responsibility form.

\section{The Rising of Disciplinary Responsibility Form}

The foundational values of sports are to struggle for reaching a personal highest performance and supremacy accompanied with the honesty of vying (Healey, 2016). Yet, a significant number of athletes are taking advantage of PEMs to reach their goals in winning titles and prizes. Consuming medicines in sports constitutes a violation of the law and leads to the disciplinary responsibility on those who are involved in doping crimes. But firstly, two conditions must be met:

(i) An act constitutes the violation of anti-doping rules: taking or giving, abstinence or negligence, or even refusing the test.

(ii) The attribution or proportion of the violation to a person: athlete, supporting team, a sports union or a national Olympic committee.

\section{An Act Constitutes the Violation of Anti-Doping Rules: Taking or Giving, Abstinence or Negligence, or Even Refusing the Test}

As a basic rule-the disciplinary system, WADA relies on the criminalization of athletes' activity on what can be found in their body's samples of residues of banned medicines, or one of its metabolic components means. The Article (2.2), paragraph (1), of the World AntiDoping Code of 2015, states that "it is each of the athlete's personal duty to make certain that no illegal material gets into his or her body and that no outlaw tactic is applied. As a result, it is not requisite that intentionality, mistake, omission or knowing use on the athlete's part is demonstrated in order to create an anti-doping rule infringement because of recruit illegal material or applying outlaw tactic." (World Anti-Doping Code 2015, 2018). So, "according to the doping control regulations, the key for the unlawful act should be linked to the 'Use' of forbidden substances or techniques. Then, the athlete is responsible for a sports crime 'if a taboo material is found to be present within a person's body tissue or fluids." (O'Leary, 2001).

They should keep their bodies 100\%, free of PEMs. Thus, their obligation is the obligation of results. If they intentionally breach this obligation "on purpose", or even without their knowledge, they are therefore personally liable in front of WADA Code for any "positive results" that appears in their samples. Under WADA rules, there is no need to have a causal link between the act of taking or given prohibited medicines or methods and the result of (chemical signs) existence in the athlete's blood. Sometimes the athlete is not aware that he or she has been given PEMs, and yet its disciplinary responsibility arises because of the existence of (metabolic elements) or the effects of a function, which means that the prohibited medicines or prohibited method has really been given. 
The Attribution or Proportion of The Violation to A Person: Athlete, Supporting Team, A Sports Union or A National Olympic Committee

It is really impossible for the Disciplinary Responsibility system to rise and for its cause to be heard, merely because there is a violation of the anti-doping rules and policies. But to make this possible there is a need for a second condition that comes together with the first one. That is:

\section{The Attribution or Proportion of The Violation to A Person}

Here we will briefly explain the status of attribution or proportion of the violation for the natural person, and then show the status of attribution or proportion of the violation for the legal person, as follows:

\section{The First Case: Attribution or Proportion of The Violation for The Natural Person}

The violation may arise and be completed by taking / giving PEMs, or by other means such as possession of prohibited substances, perhaps by the act of an "athlete" alone and without the intervention of his team. In a second form, a member (or all of the athlete's supporting team) may cause the occurrence of the violation to occur by giving the prohibited medicines to their athletes, or as a result of other acts may violate their obligation under the Code. Here, the "violation" must be attributed to both parties: the athlete who has taken the medicines, and the supporting crew of the athlete who has performed the act of "giving" or other acts that have the same legal meaning.

\section{The Second Case: Attribution or Proportion of The Violation for The Legal Person}

Sometimes a national Olympic body in a country or its local sports federations may give orders or even forcing their players, or their supporting teams who work with the athletes to give performance-enhancing medicine in order to win various sports competitions. Other times they do not comply with all their obligations under the Code. Such interference or breach of such obligations will create anti-doping rules violation. Therefore, it should (Attribution and proportion) be the violation to the National Sports Olympic Committee concerned, or to the local sports federation, which enters negatively or in breach of its obligations to the overall provisions of the Code. The work of WADA is highly valuable and indispensable, especially with regard to collecting and testing the samples. Yet, there is a sensitive issue connecting to the Anti-Doping Rules. In fact, many of the texts of the code are inconsistent with domestic national laws, in particular, penal codes. The provisions of the WADA Code are incompatible with the provisions of penal Codes. For example, the introduction (Preamble) has established a principle that is totally incompatible with criminal proceedings and thus, any criminal or civil proceedings inconsistent with its rules will not apply to any actions or activities during the sports games, even if it was considered as a crimes according to criminal or civil proceedings. This meaning is contained in the text on pages (16-17) of the 'Introduction' of the World Anti-Doping Code 2015." (AL-Dafrawi, Abdullah, Zawawi, \& Ismail, 2018). "These sport-specific rules and procedures which aimed at enforcing anti-doping rules in a global and harmonized way, are distinct in nature from criminal and civil proceedings. They are not intended to be subject to or limited by any national requirements and legal standards applicable to such proceedings," (World AntiDoping Code 2015, 2018).

"Regarding the conflict of the provisions of the WADA Code with the criminal procedures applicable within penal legislation, the researchers would like to give the following comment. 
The application of criminal proceedings to violators of laws is a basic manifestation of the sovereignty of countries. It is not legally permissible to agree on the contrary, and if a state accepts such an agreement, it, in fact, waives an important part of its sovereignty, the player who uses doping does not violate the Code only, but in fact violates the national penal law of his country. In fact, the criminal legislation of countries provides for the legal and penal protection of the human right to life and its right to bodily integrity, and since the abuse of doping affects these two rights and affects them negatively, the waiver of such protection or agreement is null and void. Consequently, the text in the preamble to the Universal Code is inconsistent with penal legal standards and in contravention of the sovereign countries' legislation." (AL-Dafrawi, Abdullah, Zawawi, \& Ismail, 2018). The conclusion or approval of such an agreement is a serious breach of the law of the player's country and the international law as well. WADA has no right to make athletes abdicate the protection provided by law to give them chance to participate in sports competitions.

\section{The Rising of Criminal Responsibility Form}

Talking about the criminal picture for actions of taking and giving performance-enhancing medicines in sports fields is not easy at all. Sometimes, these activities may begin and do not result in any serious, satisfactory or criminally consequences. Therefore, the one who is responsible for creating it or is complicit in its completeness can only be asked according to the disciplinary system form. However, it does not stop at the limit of taking or giving performance-enhancing medicines. Sometimes, it jumps to either serious or critical ill effects or to the realization of other more serious consequences like the death of athletes. In such and similar cases, it is not acceptable to speak about disciplinary responsibility to face actions and consequences affecting athletes' right to life and their right to bodily integrity. The most effective way to rule these cases goes with the criminal responsibility system form. The elements which create the ordinary crimes are almost the same elements that must exist in 'Doping Crimes':

1. "Actus Reus".

2. "Mens Rea".

3. The legal element of the crime

\section{Side Effects of Taking and Giving PEMs In the Sports Fields}

A Muscular Development magazine, has reported in its Vol. 40, No. 12 of December of 2003, an article about the duration of taking anabolic substances and their effects on the heart: "Do Steroids effect the Heart? A European team led by Dr. F. Hartgens found that athletes using steroids for $12-16$ weeks experienced no difference in blood pressure, heart wall size, or heart performance. According to this study, short-term steroids consumption did not affect heart performance or heart wall dimensions." (Muscular Development, 2003). The conclusion of this says that the short period of taking anabolic substances does not have any negative effect on the heart. This result is very right, but at the same time, it is not accurate at all because the emergence of pathological adverse effects needs long years to appear. Over and above, many performance-enhancing drugs become toxic and harmful to the point of death. "In the field of law, there are a legal determinants because in the general provisions of the Criminal laws, Standards help everyone to determine the legal description of activities of taking performance-enhancing medicines in sports. For example, the art No: (410) of Iraqi Penal Code, No. (111) for the year 1969 average, says: "by violence or by giving harmful substance ...." (Iraqi Penal Code No. 111 of 1969 Amended, 2019). Offset the art No: (330) of Jordanian Penal Code No. 16 of 1960, as amended by Law No. (8) for the year 2011, because taking and giving performance-enhancing medicines to healthy athletes falls in the meaning of 'Harmful Substance'. Also, an Athlete who injects himself/ herself, before going 
to bed with insulin leads to lower sugar level in the blood that may lead to a coma or heart failure. The logical explanation is that this man/woman wanted to do this to commit suicide (Ahmad, 2015). Anywise, there have been considerable deaths because of excess PEMs employed. Andreas Münzer lost his life when his liver shrivelled almost completely from steroids used during a cutting cycle. Michael Hall likewise died from liver disease while Don Ross and Mike Mentzer allegedly died as a result of prolonged use of anabolic steroids. Similarly, Mohammed Benaziza succeed to fulfil Steve Michalik's ideal by run out from the overuse of diuretics within hours of winning the Night of the Champions in Holland in 1993. But he died afterwards for the "art" or outstanding performance (Locks, 2012).

Legally, "anyone up doing, or facilitate to another, or contribute in raising the blood viscosity of athletes, and making it close to the level of the honey's viscosity, or appending or causing them any disruption in a body's internal organs or by adopting taking and giving performance-enhancing medicines exclusively. He/she will certainly be criminally questioned about effects caused by his/ her actions according to severity and gravity of which death is the most serious. The existence or not of criminal intent would only affect the description of the criminal acts and results behind that taking, in the punishment intensity that should be relegated on the one proved to be a perpetrator of these acts" (AL-Dafrawi A. S., Abdullah, Zawawi, \& Ismail, 2019).

\section{Conclusion}

At the end of this study, it can be said that the precise concept of doping as a human act in sports violates the law. Therefore, these violations deserve to be dealt with by disciplinary or penal code measures. In fact, these violations must be governed not only by the World AntiDoping Code, but also by the national penal law of respective countries with the greatest jurisdiction for intervention and the judgment of such cases. Athletes or their supporting teams who are taking or giving performance-enhancing medicines or uses genetic modification techniques does not, in fact, just violate the provisions of the WADA Code, but violate the domestic law of their countries in case the country has criminal legislation that penalizes doping (PEMs) in sports. Finally, we have explained the rising of criminal responsibility because of consuming prohibited medicines. We also provided pictures of the side effects that lag behind the use of drugs that promote athletic performance.

\section{Funding}

The researchers' team acknowledges that they have not received any assistance in any way or by any mean, from any Official body or private entity.

\section{Conflict of Interest}

The authors of this article, emphasize through it that was no conflicts of interest with respect to the research, authorship, and/or publication of this article.

\section{Declaration}

The authors of this article confirm that we did not mention in our article any experiments which have been carried out on human beings nor animals. Also, we did not use any hospital names.

\section{References}

Ahmad, A. S. (2011). Bodybuilding - Training Techniques and Doping Hazards (1 ed.). Amman: Dar-Dijlah, Publishers. 
Ahmad, A. S. (2015). Criminal Responsibility of Taking Physical Steroids in Sports \& Its Effects in Jordanian \& Iraqi Law: A Comparative Study. Amman: Dar Ammar for Publishing and Distribution.

AL-Dafrawi, A. S. (2018). Taking Physical Steroids in Sport Competitions: From an EthicalLegal Perspective. Journal of Political Science and Law, 2(9), 188-206.

AL-Dafrawi, A. S., Abdullah, M. A., Zawawi, M., \& Ismail, Z. (2018). Consuming Prohibited Substances in Sport Activities: A Legal and Shariah Perspective. International Journal of Fiqh and Usul Al-Fiqh Studies (IJFUS), 2(special), 23 - 37.

AL-Dafrawi, A. S., Abdullah, M. A., Zawawi, M., \& Ismail, Z. (2019). Taking steroids in the sports field: Islamic and Conventional Law perspective. International Journal of Muslim World Studies, 17(1), 318-355.

Atienza-Macías, E. (2018). Public Health Law Perspectives: Nutritional Supplements and Doping In Sports. International Journal of Law and Public Administration, 1(1), 1-7. doi:https://doi.org/10.11114/ijlpa.v1i1.3242

Bird, S., Black, N., \& Newton, P. (1997). Sports Injuries - Causes, diagnosis, treatment and prevention (1st ed.). Cheltenham: Stanley Thornes (Publishers) Ltd.

Cashmore, E. (2002). Sport Psychology: The Key Concepts. London: Routledge.

Cashmore, E. (2005). Making sense of sports (4 ed.). London: Routledge.

Chan, D. K., Ntoumanis, N., Gucciardi, D. F., Donovan, R. J., Dimmock, J. A., Hardcastle, S. J., \& Hagger, M. S. (2016, July 15). What if it really was an accident? The psychology of unintentional doping. British Journal of Sports Medicine, 50(15), none. doi:http://dx.doi.org/10.1136/bjsports-2015-094678

Coakley, J. J. (2009). Sport in Society: Issues and Controversies (10th ed.). New York: McGraw Hill Companies, Inc.

Deeksha, S., Akarsh, S., R.K, D., \& U.S, B. (2017). DOPING IN SPORTS- A REVIEW. Journal of Biomedical and Pharmaceutical Research, 6(2), 1-5. Retrieved from http://jbpr.in/index.php/jbpr/article/view/56/48

Gardiner, S., James, M., O'Leary, J., Welch, R., Blackshaw, I., Boyes, S., \& Caiger, A. (2001). SPORTS LAW (2 ed.). London: Cavendish Publishing Limited.

Geeraets, V. (2018). Ideology, Doping and the Spirit of Sport. Sport, Ethics and Philosophy, $12(03)$, 255-271. doi:https://www.tandfonline.com/doi/full/10.1080/17511321.2017.1351483

Healey, D. (2016). The Myth of the Level Playing Field in Sport. In U. Haas, \& D. Healey, Doping in Sport and the Law (1 ed., pp. 3-18). Oxford: Hart Publishing Ltd.

Hornby, A. S., \& Crowther, J. (1998). Oxford Advanced Learner's Dictionary of current English (6 ed.). Oxford: Oxford University Press.

IbnuManzwr, J. '. (2003). لِيَانُ العَرب [The Tongue of the Arabs] (1 ed., Vol. 15). Beirut: Dar AL-Kotob AL-Ilmiyah.

Iraqi Penal Code No. 111 of 1969 Amended. (2019, May 7). Article No: 410, from Iraqi Penal Code No. 111 of 1969 Amended. Retrieved May 20, 2019, from Iraqi Legislation Base: http://iraqld.hjc.iq/main_ld.aspx

Jackson, E. (2012). Law and the Regulation of Medicines. Oxford: Hart Publishing Ltd.

Lenehan, P. (2003). Anabolic steroids and other performance-enhancing drugs. London; New York: Taylor \& Francis.

Locks, A. (2012). Flayed Animals in an Abattoir: The Bodybuilder as Body-Garde. In A. L. Richardson, Critical Readings in Bodybuilding (pp. 166-180). London: Routledge.

Minigh, J. L. (2007). Sports Medicine. Connecticut: Greenwood Publishing Group, Inc.

Møller, V. (2010). The Ethics of Doping and Anti-Doping: Redeeming the Soul of Sport? (1st ed.). London: Routledge. 
Müller, R. K. (2010). History of Doping and Doping Control. In D. T. Hemmersbach, \& D. T. Hemmersbach (Ed.), Doping in Sports: Biochemical Principles, Effects and Analysis (Vol. 195, pp. 1-23). Berlin: Springer. doi:https://doi.org/10.1007/978-3-54079088-4_1

Muscular Development. (2003, December N. D.). Short-term Steroids Use Doesn't Damage Heart. Muscular Development, 40(12), p. 105.

O'Leary, J. (2001). The State of Play. In J. O'Leary, Drugs and Doping in Sport - SocioLegal perspectives (1 ed., pp. 1-9). London: Cavendish Publishing Limited.

O'Connor, B., Budgett, R., Wells, C., \& Lewis, J. (1998). Sports Injuries and Illnesses: Their Prevention and Treatment. Wiltshire: The Crowood Press.

Pattinson, S. D. (2011). Medical Law and Ethics (3 ed.). London: SWEET \& MAXWELL.

PROHIBITED LIST. (2019, JANUARY 1). M3: GENE AND CELL DOPING. Retrieved May 19, 2019, from wada-ama.org: https://www.wadaama.org/sites/default/files/wada_2019_english_prohibited_list.pdf

Rahman, E. A. (2013, August Wednesday, 07). Prescription-only by doctors. Retrieved September 10, 2019, from The Star online: https://www.thestar.com.my/opinion/letters/2013/08/07/prescription-only-by-doctors/

Russell, J. S., \& Browne, A. (2018). Performance-enhancing drugs as a collective action problem. Journal of the Philosophy of Sport, 45(2), 109-127. doi:https://doi.org/10.1080/00948705.2018.1440355

Salamin, O., Kuuranne, T., Saugy, M., \& Leuenberger, N. (2017, November-December). Loop-mediated isothermal amplification (LAMP) as an alternative to PCR: A rapid on-site detection of gene doping. Drug Testing and Analysis, 9(11-12), 1731-1737. doi:https://doi.org/10.1002/dta.2324

Soek, J. (2006). The Strict Liability Principles and the Human Rights of Athletes in Doping Cases. The Hague: T.M.C. Asser Press.

Tamburrini, C. (2007). After Doping, What? The Morality of the Genetic Engineering of Athletes. In W. J. Morgan, Ethics in SPORT (2 ed., pp. 285-298). Illinois: Human Kinetics.

United Nations Educational, Scientific and Cultural organization (UNESCO). ( 2005, October 19). International Convention against Doping in Sport 2005. Retrieved May 10, 2019, from unesco.org: http://portal.unesco.org/en/ev.phpURL_ID=31037\&URL_DO=DO_TOPIC\&URL_SECTION=201.html

Vargas-Mendoza, N., Fregoso-Aguilar, T., Madrigal-Santillán, E., Morales-González, Á., \& Morales-González, J. A. (2018). Ethical Concerns in Sport: When the Will to Win Exceed the Spirit of Sport. Behavioral Sciences, 8(9), 1-18. doi:https://doi.org/10.3390/bs8090078

World Anti-Doping Code 2015. (2018, April 1). "Article 2.2: Use or Attempted Use by an Athlete of a Prohibited Substance or a Prohibited Method", WORLD ANTI-DOPING CODE 2015 with 2018 amendments. Retrieved May 20, 2019, from wada-ama.org: https://www.wada-ama.org/sites/default/files/resources/files/wada_antidoping_code_2018_english_final.pdf

World Anti-Doping Code 2015. (2018, April 1). "Part One: Doping Control-Introduction", WORLD ANTI-DOPING CODE 2015 with 2018 amendments. Retrieved May 20, 2019, from wada-ama.org: https://www.wadaama.org/sites/default/files/resources/files/wada_antidoping_code_2018_english_final.pdf

World Anti-Doping Code 2015. (2018, April 1). "art 4.4.1: Therapeutic Use Exemptions (“TUEs")", WORLD ANTI-DOPING CODE 2015, with 2018 amendments. Retrieved May 17, 2019, from wada-ama.org: https://www.wada- 
ama.org/sites/default/files/resources/files/wada_antidoping_code_2018_english_final.pdf

Yesalis, C. E. (Ed.). (2000). Anabolic Steroids in Sport and Exercise (2nd ed.). Illinois: Human Kinetics Publishers. 